\title{
THE PHRASE “KRIVORAZBRANA TOLERANTNOST” IN BULGARIAN MATERNITY FORUM COMMUNICATION
}

\author{
Bilyana Todorova \\ ORCID: 0000-0001-7854-3425 \\ Scopus Author ID: 57200216276 \\ b_stoianova@hotmail.com \\ South-West University “Neofit Rilski”, Bulgaria
}

\section{Received March 12, 2020; Revised March 27, 2020; Accepted May 28, 2020}

\begin{abstract}
The aim of the research is to present the meaning and the scope of the phrase "krivorazbrana tolerantnost" (misunderstood tolerance), which functions as a cliché in everyday communication. The corpus is excerpted from the largest Bulgarian forum platform - bg-mamma and investigates the use of 55 phrases between 2006 and 2017. "Krivorazbrana tolerantnost" is used in public communication to express disagreement with someone's behaviour/point of view or fear of the changing habits or traditions. Using the cognitive ethnolinguistic approach as well as corpus-based discourse techniques, the paper focuses on the corpus uses of the phrase, its pragmatic influence on the dialogue and the people or the topics which are usually an object of misunderstood tolerance according to bg-mamma forum users. The results show that the context meaning of the phrase usually is overtolerance or too much permissiveness and it is used in conversations, discussing the rights and liberties of different groups and minorities. As the tolerance itself is a kind of forcing oneself to accept something one does not support or believe in, its meaning and the contextual meaning of the investigated collocation are close.
\end{abstract}

Keywords: misunderstood tolerance, pragmatic use, public discourse, forum communication.

Біляна Тодорова. Вираз «krivorazbrana tolerantnost (невірно інтерпретована толерантність)» у комунікації на форумах матерів у Болгарії

Анотація. Мета дослідження - представити значення та наповненість виразу "krivorazbrana tolerantnost" (невірно інтерпретована толерантність), який функціонує як кліше у повсякденному спілкуванні. Корпус відібрано із найбільшої болгарської платформи для форумів - bg-татта і проаналізовано вживання 55 виразів між 2006 та 2017 роками. "Krivorazbrana tolerantnost" (невірно інтерпретована толерантність) вживається у публічному спілкуванні для вираження незгоди з чиєюсь поведінкою чи поглядом або для вираження страху перед зміною звичок чи традицій. Застосовуючи етнолінгвістичний підхід разом із корпусно-базованими методами аналізу дискурсу, увагу в дослідженні зосереджено на вживанні цього виразу в корпусі, його прагматичному впливі на діалог, людей чи теми, які $\epsilon$ зазвичай об'єктом невірно інтерпретованої толерантності, згідно з користувачами форуму $b g$ татта. Результати доводять, що контекстуальним значенням виразу зазвичай $\epsilon$ надмірна толерантність або надмірна вседозволеність, і він використовується у розмовах при обговоренні прав та свобод різних груп та меншин. Оскільки власне толерантність - це спосіб спонукання себе прийняти щось, що людина не схвалює чи у що не вірить, то ії значення та контекстуальне значення досліджуваного виразу є близькими.

Ключові слова: невірно інтерпретована толерантність, прагматичне вживання, публічний дискурс, спілкування у форумі.

(C) Todorova, Bilyana, 2020. This is an Open Access article distributed under the terms and conditions of the Creative Commons Attribution 4.0 International Licence (http://creativecommons.org/licenses/by/4.0).

East European Journal of Psycholinguistics, 7(1), 171-183. https://doi.org/10.29038/eejpl.2020.7.1.tod 


\section{Introduction}

\subsection{Tolerance as a concept}

The word толерантност (tolerance, toleration) in Bulgarian (as in English) is of Latin origin - the Latin word is tolerantia "a bearing, supporting, endurance." ${ }^{11}$ Its popularity in the Bulgarian context is relatively late - the first use of the root of the word is in 1883 when the adjective толерантен 'tolerant' is mentioned (Todorova, 2019). The noun is used in 1890 in the Balkan dawn newspaper ${ }^{2}$ which is the first lasting daily Bulgarian newspaper published in Plovdiv from 1890 to 1894 and from 1 to 4 October 1900. The adjective was more popular in the first decades of the 20 th $^{\mathrm{h}}$ century and it is the preferred word in dictionaries whereas the noun is presented as a derivative from the adjective. In Bulgarian, it has the same root as in other languages. However, the suffix in Bulgarian is the same as in the other East Slavic languages and differs from the West Slavic and South Slavic languages (maybe because of the Russian influence in the period).

Because of its global popularity, the concept of tolerance becomes very important but ambiguous in its understanding. Definitions in Bulgarian dictionaries are few and they often duplicate. For example, the definition in the Official Dictionary of Bulgarian language includes firstly the adjective: tolerant - "who shows lenity, latitude toward other opinion, character, religion, etc." ${ }^{3}$, and the noun is explained as: tolerance $e^{4}$ - abstract noun from tolerant. Latitude and leniency are seen as close synonyms, but as a whole, the word is not well explained and the definitions are the same.

As it was said, the use of the word is more frequent nowadays, as tolerance is one of the main values of the pluralist liberal democracy. It may be seen in UNESCO's Declaration of Principles of Tolerance, where tolerance is defined as: "respect, acceptance and appreciation of the rich diversity of our world's cultures, our forms of expression and ways of being human." At the same time, it is outlined that "the practice of tolerance does not mean toleration of social injustice or the abandonment or weakening of one's convictions." ${ }^{5}$

Tolerance is also understood as a minimal concept that involves noninterference with practices or forms of life of others, including granting equal legal and political rights even if one disapproves of them.” (Nizah et al., 2015, p. 366). Therefore tolerance is a result of a conscious decision, it is not necessarily naturally inherent in humans, it is an understanding related to the development of human civilisation and the idea of human rights, pluralism, democracy and the rule of law. That is why it is used in contexts connected to the minority groups and their 'social inclusion'.

\footnotetext{
${ }^{1}$ According to Latdict - ability to bear/endure pain/adversity; patience, fortitude, tolerance. http://www.latindictionary.net/definition/37271/tolerantia-tolerantiae

${ }^{2}$ In Bulgarian “Балканска зора", № 66

${ }^{3}$ http://bl.bas.bg/ibelangbg\%D1\%82\%D0\%BE\%D0\%BB\%D0\%B5\%D1\%80\%D0\%B0\%D0\%BD\%D1\%82\%D0\%B5\%D0\%BD/

${ }^{4}$ http://ibl.bas.bg/belangbg\%D1\%82\%D0\%BE\%D0\%BB\%D0\%B5\%D1\%80\%D0\%B0\%D0\%BD\%D1\%82\%D0\%BD\%D0\%BE\%D1\%81 $\% \mathrm{D} 1 \% 82$

${ }^{5}$ UNESCO’s Declaration of Principles on Tolerance, 16 November 1995 http://portal.unesco.org/en/ev.phpURL_ID=13175\&URL_DO=DO_TOPIC\&URL_SECTION=201.html
} 
Meanwhile, we have recently observed the growing of exclusion narratives and inclinations. The minority rights are contradicted to the need of majority to save their own positions, traditions and privileges.

It is known that the intolerant, racist and nationalistic statements are a part of the public discourse in many European countries and they are gaining more popularity. These attitudes have attracted the attention of a large number of discourse-oriented researchers (Wodak \& Reisigl, 2001, Tateo, 2008; Dijk 2015; Brindle, 2016; Musolf, 2017, etc.). At its centre is the fear of others, whose roots are often in the past, which is a reality at the present and is oriented to the future. As Arias \& Bryla (2018, p. 2) said: "although the fear of the other which Shteyngart is writing about in his memoir is felt in the present, it is in fact located in the future, operating as an open-ended threat, or an always valid possibility, whose affective force is so strong that it refuses to be rationalized". The fear of the others results in the so-called "hate speech" which is a part of Bulgarian public speech as well.

In Bulgarian few authors are tempted by the topic of tolerance these days. The first one is Elka Dobreva who was interested in the concepts of tolerance, intolerance and null tolerance in the print press. Her definition of the term is: "Tolerance is considered in cases when the tolerated subject (1) does not approve of or like certain qualities or actions of the tolerated person, but (2) voluntarily refuses to pursue, restrict or terrorize the tolerated person.” (Dobreva, 2009, p. 23) ${ }^{1}$. The problem is also discussed by Eftimova (2016), Kreychova \& Stalyanova (2017), Todorova (2019), but as a whole, it is not well developed in the Bulgarian context by researchers.

The word tolerance (,толерантност") is used in political and media discourse and at the same time in everyday communication. The informal public or private discourse is extremely interesting for the researcher because official texts are usually more neutral and premeditated (politically correct) and therefore informal discourses represent more specific meanings of the investigated lexeme. This is especially true when the collocations containing this word are used expressively as clichés, as ready-made phrases.

\section{Methods and Theoretical Frame of the Research}

The main theoretical frame of the research is a cognitive ethnolinguistic view of Jerzy Bartminski. The Cognitive Ethnolinguistic School of Lublin investigates different concepts, one of which is tolerance. According to Bartminski (2002, p. 380), ethnolinguistics is "a branch of linguistics that deals with language in its relations to the history of particular communities (environmental, regional, national) and their culture, esp. to group mentality, behaviours, and value systems". The advantage of the investigation of some important concepts and values from this view is the investigation not only of their literal meaning in dictionaries but the subjective ethno specific features which the word possesses in speech. In some kind, it is close to the CDA approach, as it is evaluative as well. As we know CDA "is not

\footnotetext{
${ }^{1}$ Translation is mine, B.T.
} 
interested in investigating a linguistic unit per se but in studying social phenomena which are necessarily complex and thus require a multi-disciplinary and multimethodical approach” (Wodak \& Meyer, 2001, p. 2).

The method is close to the ethnographic point of view: "In practice, ethnography as a methodology and distinct approach involves the direct entry of the researcher into a particular context and their participation in or observation of local practices over an extended period] ... [This involves collecting several kinds of data in addition to observation, such as participants' accounts of their own practices, various types of narratives, images, documents, etc. (Wodak \& Savski, 2018, p. 94).

Bartminski and Chlebda (2008) point out four basic types of data that guide inquiries into the content of axiological concepts: lexicographic data, texts, derived from excerpts from public discourse, corpus data (language corpora and Internet searches), and experimental data (see more in: Niebrzegowska-Bartminska, 2018, p. 17). In this paper, the focus is only on the corpus data, and especially on the use of the phrase "криворазбрана толерантност" (misunderstood tolerance) in the largest Bulgarian forum, bg-mamma.

\section{The study}

\subsection{Aim, objectives and corpus of investigation}

The aim of the research is to show the meaning and the scope of the phrase "криворазбрана толерантност" (misunderstood tolerance). The corpus is excerpted from the largest Bulgarian forum platform - bg-mamma. Bg-mamma communication is (partly) anonymous, dialogic, asynchronous and topic-centred. However, some active users form spontaneous communities united by shared topics of interests and their relationships become closer - they express their points of view defending or attacking some positions of the previous posts. So the hypothesis is that the investigated phrase as many others may function as a means to approve the previous negative reaction or as a means for expressing discrepancy. The interpersonal aspect of researched forum communication is very interesting because of the plausible and context-dependent meaning of the investigated phrase. By the help of the search engine of the platform all uses of the investigated phrase are collected - these are 55 uses of the phrase between 22.08.2006 - 04.06.2017. The phrase is not a part of any dictionary and it couldn't be found by the search engine of the Bulgarian reference corpus BulTree Bank ${ }^{1}$.

The research includes also the inspection of the immediate context - the topic of the conversations, the positions defended, etc. The context observation will present the pragmatic function of the uses as well as the social prejudices and stereotypes they promote. The full description of these uses may reveal the meaning of the phrase according to forum users.

As a result, the following objectives of the research are formulated:

- To describe the pragmatic functions of the phrase

\footnotetext{
${ }^{1}$ http://webclark.org/ 19.04.2020
} 
- To reveal the liberties which are not acceptable according to users who are writing in the platform and the objects of the so-called криворазбрана толерантност.

- To reveal the general meaning of the phrase.

The complex adjective 'криворазбран' is formed by the word „крив“ (curved, awry, guilty) and „разбран” the past passive participle of the verb „разбера“ (understand)“. In Bulgarian context the word „криворазбран“ is known from the 19th century because of the one of the most significant Revival's comedies “Криворазбраната цивилизация“ (“The Phoney civilization”) by Voynikov. In the comedy the traditional Bulgarian values and understandings are defended and the influence of the modern foreign manners and trends is denied. Therefore the word „криворазбран“ ассерts the meaning of "not properly understood, distorted, perverted"1.

\subsection{Clichés in Communication}

As it was said before, the use of the phrase is widespread in public discourse as well as in everyday communication. The meaning of isolated lexemes has been explained, but the meaning of the whole ready-made phrase is more important. The hypothesis is that the pragmatic function of the collocation is to express disagreement with someone's behaviour or point of view or fear of the changing habits or traditions. The phrase functions as a cliché and the preliminary observations show that it usually presents anti-liberal attitudes.

Clichés are often used to express a pragmatic meaning because of their potential to save time, to express approval or disapproval, emotions, etc. The pragmatic force of ready-made phrases is mentioned in Steinbrich (2016, p. 129) who claims that "set groups exhibit pragmatic functions and include proverbs, sayings, clichés, catchphrases and slogans". Pragmatic meanings of one phrase may be different and they depend on the immediate context.

It is known that by the help of different linguistic means we may express agreement, disagreement, mitigation, etc. Like pragmatic markers, all uses with pragmatic function organise or modify the conversation and reveal the personal attitude of the speaker. Therefore the research includes the investigation of discussed topics in which the phrase is used as well as the investigation of positions which their authors support. The background of the use of the phrase and the semantic confusion it contains presuppose their use in negative contexts. However, data research may reveal the relationship between the author's expectations and their realisation.

\section{Results and Discussion}

The use of the phrase is in the conversation and usually, it appears in some discussions when people confess something or argue with somebody. People express their point of view defending or attacking the positions of the previous

\footnotetext{
${ }^{1}$ In the paper the phrase is translated as 'misunderstood tolerance' (thereafter MT)
} 
posts. As a result, the investigated phrase may function both as a means of approving the previous negative reaction $(1,2)$ or as a means for expressing discrepancy (3):

(1) именно. криворазбрана толерантност е да се търпи парадирането с религиозност особено сега, когато територията на ияла една държава е окупирана от религиозни терористи. ако някой иска да промотира религията си - да го направи с добри действия и добро отношение, а не с "вижте ме колко по-различен съм от вас и колко по-права е вярата ми.(Indeed. A misunderstood tolerance is to endure the swaggering religiosity, especially now when the territory of the whole country is occupied by religious terrorists. If someone wants to promote their religion - they should do so with good deeds and a good attitude, not with "look how different I am and how better my faith is.)

(2) Абсолютно съм съгласна, точно така е! Напоследък забелязвам едно много странно явление - интелигентни и възпитани родители с ужасно лигави деца, които или са оставени на "самотек" да си правят каквото си искат (от някаква криворазбрана толерантност ли що ли) или когато родителя прави някакъв плах опит да се наложи настава голяма драма и нищо не се получава...(I absolutely agree, that's right! I have noticed recently a very strange phenomenon - intelligent and educated parents with terribly naughty children who are either left alone to do whatever they want (this is a sort of misunderstood tolerance maybe) or when the parent makes some sort of timid attempt to decide something then a big drama starts and nothing happens ...)

The use of means of expressing approvement like именно (indeed), абсолютно съм съгласна, точно така е (I absolutely agree, that's right!) show that the posts are responses, reactions to previous opinions and support the presented negative position.

(3) А. Не казвам, че е редно да крещи така, когато в къщата й има дете. Но не съм и сигурна, че това е единственото нещо, което дразни дъщерята.

Б.Ами разбира се, че не е само крещенето, тя си го казва, влаченето на различни любовници у дома просто не е редно. Аман от криворазбрана толерантност. (A. Just a minute. I don't say she should scream in such a way when her child is at home. But I'm not sure it is the only thing that annoys the daughter.

B. Well, of course, it's not just screaming. She confesses - inviting different lovers at home is just unacceptable. I am sick and tired of misunderstood tolerance.)

The first user tries to excuse the behaviour of the mother who screams at her daughter. The second user doesn't accept the excuse and adds another problem - the "amoral" behaviour of the mother. The author finishes with an investigated phrase, combined with an identifier "аман" used to show disapproval, impatience and even rejection.

\footnotetext{
${ }^{1}$ From Arabic through Turkish aman 'mercy, protection'.

${ }^{2}$ https://ibl.bas.bg/rbe/lang/bg/\%D0\%B0\%D0\%BC\%D0\%B0\%D0\%BD/ 
Consequently, the investigated syntagm functions as a cliché, it’s highly expressive and may approve or disapprove of the previous post(s). Usually, it is used with a combination of other expressive phrases (аман, писна ми, (enough of/ sick and tired of) etc.). The topic of the conversation may be different and there are some hotspots - school aggression, social privileges, minority rights, etc. To present the proper analysis, the author has collected the uses and has divided them according to the topic, investigating the most unacceptable liberties according to bgmamma users.

\subsection{Thematic division of the topics of misunderstood tolerance: Religious liberties}

17 out of 55 examples concern religion, more often the Muslim one. In some cases, only the extremist parts of the religious groups are objects of misunderstood tolerance according to users. In other cases, the opinions are more general and unspecified, or they are connected to religious elements and symbols. In fact, although the bigger part of Bulgarians are Orthodox Christians, there has been a Muslim minority for a long time as Bulgaria had been a part of the Ottoman Empire. Most of the time Orthodox Christians and Muslims have been living in peace (except for the so-called Възродителен проиес 'Process of Rebirth' in 1989). However, the collective memory of the times when the Bulgarian territory was a part of the foreign Muslim empire is still alive and helps people to see the Muslim religion as a threat for the secular state and for the local traditions and habits.

Кога ли в някоя мюсюлманска държава ще публикуват книга примерно с заглавие "аз и хомосексуалното ми братче" или "жените равни на мъжа"? Не разбирам до кога с тази криворазбрана толерантност у защо ние трябва да приемаме тяхните иенности и порядки? (Whenever in a Muslim country will they publish a book entitled "Me and My Homosexual Little Brother" or "Women Are Equal to Men", for example? I do not understand how long this misunderstood tolerance will continue, why should we accept their values and habits?)

\section{LGBT rights}

People with alternative sexual orientation are also seen as tolerated. Such discussions are usually started at the time of the year when Sofia Pride event takes place. However, the Istanbul Convention ratification, which was postponed because of mass protest and the Law of Child protection also triggered some fears about possibility LGBT people to receive some excessive rights. 9 out of 55 examples are linked with the people with a different sexual orientation:

Относно еднополовите връзки ние с ММ и двамата сме крайно нетолерантни и смятаме това за извращения, а гейпарадите за натрапена показност в името на криворазбрана ,,толерантност”...(Concerning same-sex relationships, we (my husband and I) are both extremely intolerant, and we consider them to be perverse, and the gay parades for intimidation in the name of misunderstood "tolerance" ...) 


\section{Children's rights}

As the investigated platform $b g$-mamma is a maternity forum, most of the users express their opinion of parenting, children's education, etc. Although in Bulgarian traditional view children are very special and the attitude towards them is positive and even indulgent, there are a lot of people who are supporters of stronger parenting models and educational practices. 7 out of 55 examples concern kids and their behaviour.

На мен ми се струва, че от криворазбрана свобода, толерантност, разбиране на деиата и др. подобни още от ранна възраст положението $c$ днешната младеж, че и деиа на по 5-6z. е такова. (It seems to me that because of misunderstood freedom, tolerance, understanding of children, etc. from the very early age, there is such a situation with young people and with children who are 5 or 6 years old.)

\section{Roma people rights}

According to the Bulgarian National Statistical Institute, ${ }^{1} 280979$ Roma people lived in Bulgaria in 2011. They are perhaps more as "one part of the Muslim Roma in Bulgaria is also Turkish speaking and they identify in most of the cases as Turks” (Kyuchukov, 2019, p. 32). Roma minority has specific culture and traditions, Roma people usually live separated in ghettos on the outskirts of towns and villages. They are often accused (even in public) because of their mentality, low education, early marriages, high birth rate, high unemployment rate, etc. Nationalistic parties, some of which are a part of the Bulgarian coalition government, use anti-Roma rhetoric and their members often speak about the Roma threat. 5 out of 55 examples are connected to the Roma people, their behaviour and their liberties:

сега вече са РОМИ по тяхно настояване - хитри, мързеливи, крадливи, озлобени, не зачитащи нищо и никого, все за нещо сме им дльжни, те са продукт на новата ни демокрация и нейната така наречен толерантност, която е криворазбрана. (now they are Roma people at their insistence - cunning, lazy, thieving, enraged, not respecting anything and anybody, we always owe them something, they are the product of our new democracy and its so-called tolerance which is misunderstood.)

\section{Refugees/Asylum seekers/ Migrants' rights}

5 out of 55 uses are linked with the behaviour of the refugees/asylum seekers/migrants. In the forum texts, these terms are used as synonyms. The opinions are usually extreme and the users present their disagreement with the habits of the people from these groups:

Аман от криворазбрана толерантност, бих казала аз! Може някой ияла нощ да ти крещи, хвърля боклуци по главата, и ияапа, но е нужно да мълчиш, защото трябва да си толерантен. Хората от Овча купел, също са принудени да търпят дивотиите на сирийските бежанци, щото видите ли такъв им бил манталитета на тях и трябва да се примирим. Идват на орди с десетте си деца всеки, размахват ни пръст, че нямали условия за живот, нямали работа,

\footnotetext{
${ }^{1}$ https://censusresults.nsi.bg/Census/Reports/2/2/R9.aspx 
нямали пари, и пак трябва да сме толерантни, да ги обгрижваме , да ги издържаме. (Enough of misunderstood tolerance, I would say! Someone may scream all night, they throw junk on people's heads and make a mess, but you have to keep silent because you have to be tolerant. People from Ovcha Kupel Quarter are also forced to endure the oddities of Syrian refugees, excusing their actions because of their traditions and culture, and we must put up with them. They come in hordes with their ten children, scolding us that they have no living conditions, no jobs, no money, and we have to be tolerant, caring, we have to finance them.)

The topics are often mixed - for example the migrants' problem is connected to the one concerning religious liberties. The fear of radical Islam results in the fear of Muslims as a whole. As Arias \& Bryla (2018, p. 2) write: "A similar fear of otherness understood not as physical presence but as a what if scenario may be detected in the anti-refugee discourse of social and political spaces of present-day Europe":

Таис, аз живея от 15 години в Германия, имам и немски паспорт, чувствам се добре тук и досега нямах никакво намерение да се връщам в България. Признавам си обаче, че ако този ужас с тези мюсюлмански бежанци от мъжки пол тук продължи още няколко години, аз най-вероятно ще се върна в България, защото чисто и просто като жена мен ме е страх от тях. Работя в сочиалния сектор и виждам как се държат и какви прененции имат, и най-лошото е, че имам чувството, че голяма част от хората тук си мислят, че са длъжни да ги търпят от някаква криворазбрана толерантност. (Tais, I have lived in Germany for 15 years, I also have a German passport, I feel good here and so far I have had no intention of returning to Bulgaria. However, I confess that if this horror with the Muslim male refugees will continue here for a few more years, I will most likely return to Bulgaria, because purely and simply as a woman, I am afraid of them. I work in the social sector and I see how they behave and what they have, and the worst part is that I get the feeling that most of the people here think they have to be tolerant with them because of some misunderstood tolerance.)

\section{Miscellaneous}

The rest of the excerpted uses concern different topics, including concrete groups of people like aggressive people, smokers, non-professionals, pedophiles, drug addicted and some abstract notions like пошлостта (vulgarity), свободията (too much freedom), etc. What is common in them is the negative connotation to these people/ideas. However, there are 3 uses out of 55 in which the meaning of the phrase is 'the lack of tolerance' and in these cases, the discussed groups of people are seen as insufficiently tolerated, as suffered by the others.

In conclusion, the thematic division has shown who is affected by the so-called криворазбрана толерантност (MT). The results make it clear that there are several types of people, qualities or things who/which are objects of "misunderstood tolerance": the so-called "others", who break the social norms - social parasites, aggressive children, children who have a lot of claims and pretensions; homosexual people, vegans, etc.; those who do not behave professionally when they have to - 
some doctors or teachers, etc.; those who are seen as privileged according to users; those who threat the demogranhic and religious nicture of societv: those who hreak a kind of moral norms; those who break the social norms in a physical aspect - for example, people who smell, etc. (See Figure 1, where all the uses are listed). ${ }^{1}$

Figure 1

Thematic division of the topics of the misunderstood tolerance

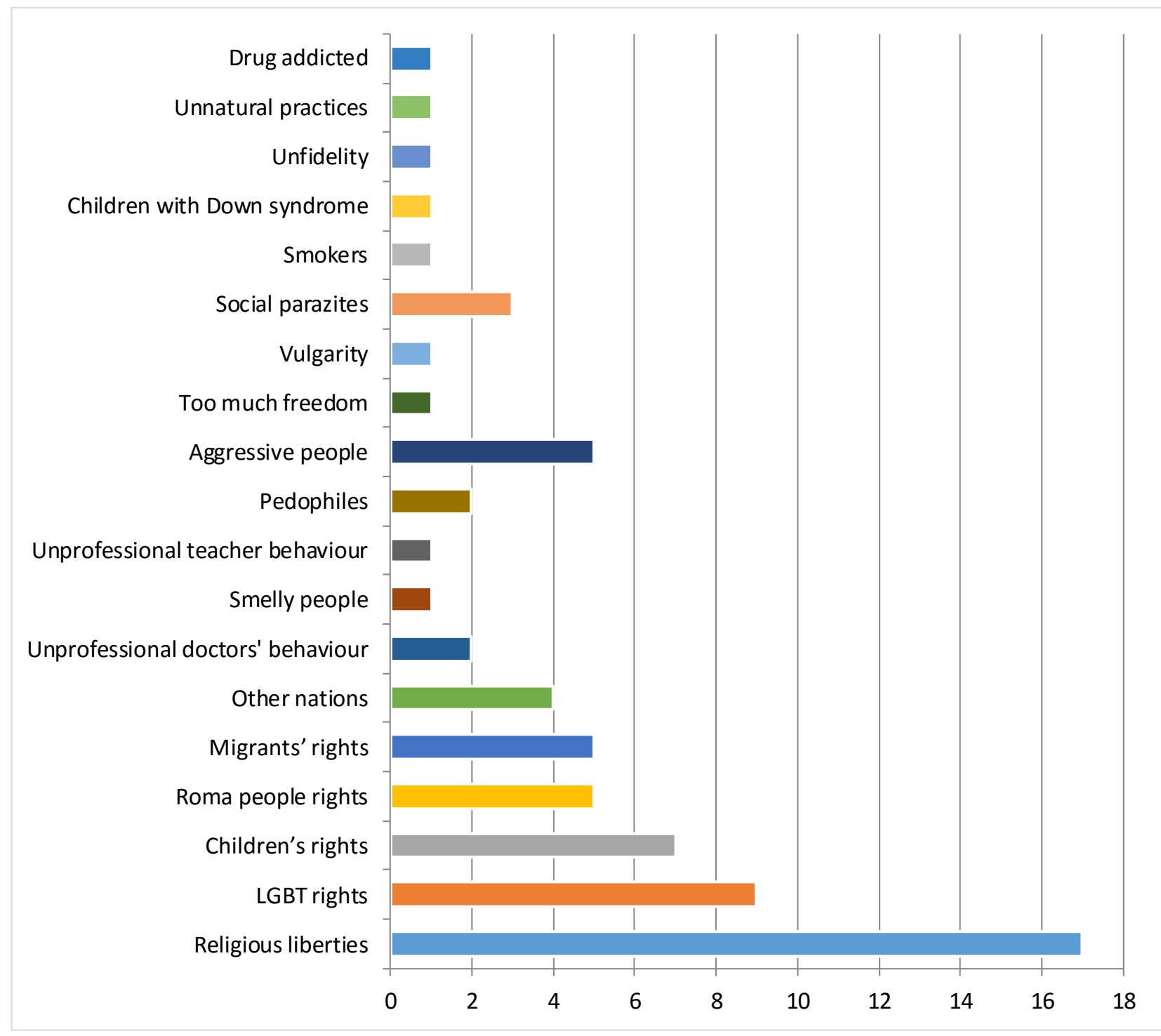

\subsection{The meaning of the phrase криворазбрана толерантност 'misunderstood tolerance'}

Having in mind the contextual uses of the phrase, one may conclude that the phrase usually means over-tolerance or too much permissiveness. As was argued before, there are some exceptions when it means the lack of tolerance (3 out of 55). In fact, except for some additional connotations, the definition of misunderstood

\footnotetext{
${ }^{1}$ The total number of uses exceeds 55 as some uses refer to more than one topic.
} 
tolerance looks the same as the definition of tolerance. The majority of users mean that:

- Because of MT people suppress themselves;

- Because of it they are inclined to understand/do not correct unacceptable behaviour; to defend the rights of those who are guilty, so as to expose people to dangers;

- MT stiffens and people suffer because of it;

- Because of MT people deny their natural instincts;

- Because of MT people accept those who are different, therefore the MT makes people meek, good, modest;

- Because of MT people say things politely and do not tell the truth

- Last, but not least: the manifestation of MT leads to the lack of respect for the symbols and national pride.

\section{Conclusions}

The uses of the phrase „криворазбрана толерантност“ (misunderstood tolerance) in the bg-mamma forum present that its meaning often covers the meanings of the tolerance itself. As was said before tolerance means 'to accept the people who are different'. At the same time, it is clear that the majority of people, these who represent the so-called normality, sometimes feel endangered and they think that some liberties are unacceptable, that tolerance is in fact over-tolerance. It is a widespread opinion that all the people must have the same rights and the same obligations. The objective evaluation of the rights and obligations is very difficult indeed. As a result, the subjective comments will be used in the public sphere representing the sense of existing injustice; indicating some attitudes and positions to some social phenomena. The fear of others, as well as the fear of the loss of harmony, the loss of the present social order, are at the centre of these inclinations. It is important for politicians, journalists, researchers to have these opinions in mind as the language use expresses some social inclinations which may be important for all of us. They will help some social discussions which address the "hot issues" in society to be started so the social tension to be overcome and the problems to be properly solved.

\section{References}

Arias, R. and Bryla, M. (2018) Orientation towards otherness in the social and literary spaces of today's Europe. Palgrave Communication, 4(18), Retrieved from https://www.nature.com/articles/s41599-018-0070-3. https://doi.org/10.1057/s41599-0180070-3

Bartmiński, J. (2009) Aspects of Cognitive Ethnolinguistics, Sheffield: Equinox.

Bartminski, J. and Chlebda, W. (2008) Jak badac jezykowo-kulturowy obraz swiata Słowian i ich sasiadów?, Etnolingwistyka, 20, 11-27.

Brindle, A. (2016) The Language of Hate: A Corpus Linguistic Analysis of White Supremacist Language. Abingdon: Routledge. 
Добрева Е. (2009) Толерантност, нетолерантност и нулева толерантност в съвременния български печат (Критически лингвосемиотичен анализ). В. Търново: Фабер.

Ефтимова А. (2016) Двойственият език в медиите: езикът на политическата коректност vs езика на омразата. София: Парадигма.

Kreytchova, El., Stalyanova, N. (2017). The Power of Public Speech. Sofia: Paradigma.

Kyuchukov, H. (2019). Aquisition of Turkish Grammatical Categories in Bilingual Context. East European Journal of Psycholinguistics, 6(1), 32-46. https://doi.org/10.5281/zenodo.3375406

Musolff, A. (2017) Language aggression in public debates on immigration. Journal of Language Aggression and Conflict, 5(2), 175-177. https://doi.org/10.1075/jlac.5.2.01mus

Niebrzegowska-Bartmińska, S., (2018) What data are relevant to ethnolinguistic analyses?, Ethnolinguistics, 29, 11-29. https://doi.org/10.17951/et.2017.29.11

Nizah, M., Jawan, J., Singh, Sarjit, S., Samsu, K. (2015) Framing Ethnic Tolerance, Political Tolerance and Voting Behaviour. Mediterranean Journal of Social Sciences, 6(4), 365373. https://doi.org/10.5901/mjss.2015.v6n4s1p365

Steinbrich, P. (2016) Creating Academic Text: The Use of Lexical Syntagms by L2 Undergraduate Students of English. In: H. Chodkiewicz, P. Steinbrich, (Eds.). Working with Text and Around Text in Foreign Language Environments, (pp.125-141).

M. Krzemińska-Adamek. Springer. https://doi.org/10.1007/978-3-319-33272-7_8

Tateo, L. (2008) The "fascist" discourse in computer mediated communication: the "dual strategy" model of the Italian Extreme Right. Psicologia \& Sociedade, 20(2).

Тодорова Б. (2019) Някои наблюдения върху концепта ТОЛЕРАНТНОСТ в българския език. In: Ed. by S. Niebrzegowska-Bartmińska \& D. Pazio-Wlazłowska, (Eds.). Wartości w językowo-kulturowym obrazie świata Słowian i ich sąsiadów. Jedność w różnorodności. Wokół słowiańskiej aksjosfery. (pp. 307-320). Lublin: UMCS.

Van Dijk, T. (2015) Racism in the Press. In: N. Bonvillain, (Ed.). Handbook of Linguistic Anthropology. (pp. 384-392). London: Routledge,

Wodak, R. \& K. Savski (2018) Critical Discourse-Ethnographic Approaches to Language Policy. In: J. W. Tollefson and M. Pérez-Milans, (Eds.). The Oxford Handbook of Language Policy and Planning. (pp. 93-112). NY: Oxford Univ. Press. https://doi.org/10.1093/oxfordhb/9780190458898.013.4

Wodak, R., Meyer M. (2001) Methods of Critical Discourse Analysis. London: SAGE. http://dx.doi.org/10.4135/9780857028020

Wodak, R., Reisigl, M. (2001) The Semiotics of Racism. Approaches in Critical Discourse Analysis. Vienna: Passagen Verlag.

\section{References (translated and transliterated)}

Arias, R. and Bryla, M. (2018) Orientation towards otherness in the social and literary spaces of today's Europe. Palgrave Communication, 4(18), Retrieved from:

https://www.nature.com/articles/s41599-018-0070-3. https://doi.org/10.1057/s41599-0180070-3

Bartmiński, J. (2009) Aspects of Cognitive Ethnolinguistics, Sheffield: Equinox.

Bartminski, J. and Chlebda, W. (2008) Jak badac jezykowo-kulturowy obraz swiata Słowian i ich sasiadów?, Etnolingwistyka, 20,11-27.

Brindle, A. (2016) The Language of Hate: A Corpus Linguistic Analysis of White Supremacist Language. Abingdon: Routledge.

Dobreva, E. (2009) Tolerantnost, netolerantnost i nuleva tolerantnost v savremennia balgarski pechat (Kriticheski lingvosemiotichen analiz). V. Tarnovo: Faber.

Eftimova, A. (2016) Dvoystveniyat ezik v mediite: ezikat na politicheskata korektnost vs ezika na omrazata. Sofia: Prosveta.

Kreytchova, El., Stalyanova, N. (2017). The Power of Public Speech. Sofia: Paradigma. 
Kyuchukov, H. (2019) Aquisition of Turkish Grammatical Categories in Bilingual Context. East European Journal of Psycholinguistics, 6(1), 32-46. https://doi.org/10.5281/zenodo.3375406

Musolff, A. (2017) Language aggression in public debates on immigration. Journal of Language Aggression and Conflict, 5(2), 175-177. https://doi.org/10.1075/jlac.5.2.01mus

Niebrzegowska-Bartmińska, S., (2018) What data are relevant to ethnolinguistic analyses?, Ethnolinguistics, 29, 11-29. https://doi.org/10.17951/et.2017.29.11

Nizah, M., Jawan, J., Singh, Sarjit, S., Samsu, K. (2015) Framing Ethnic Tolerance, Political Tolerance and Voting Behaviour. Mediterranean Journal of Social Sciences, 6(4), 365373. https://doi.org/10.5901/mjss.2015.v6n4s1p365

Steinbrich, P. (2016) Creating Academic Text: The Use of Lexical Syntagms by L2 Undergraduate Students of English. In: H. Chodkiewicz, P. Steinbrich, (Eds.). Working with Text and Around Text in Foreign Language Environments, (pp.125-141).

M. Krzemińska-Adamek. Springer. https://doi.org/10.1007/978-3-319-33272-7_8

Tateo, L. (2008) The "fascist" discourse in computer mediated communication: the "dual strategy" model of the Italian Extreme Right. Psicologia \& Sociedade, 20(2).

Todorova, B. (2019) Nyakoi nablyudenia varhu kontsepta TOLERANTNOST v balgarskia ezik. In: Ed. by S. Niebrzegowska-Bartmińska \& D. Pazio-Wlazłowska, (Eds.). Wartości w językowo-kulturowym obrazie świata Słowian i ich sąsiadów. Jedność w różnorodności. Wokół słowiańskiej aksjosfery. (pp. 307-320). Lublin: UMCS.

Van Dijk, T. (2015) Racism in the Press. In: N. Bonvillain, (Ed.). Handbook of Linguistic Anthropology. (pp. 384-392). London: Routledge.

Wodak, R. \& K. Savski (2018) Critical Discourse-Ethnographic Approaches to Language Policy. In: J. W. Tollefson and M. Pérez-Milans, (Eds.). The Oxford Handbook of Language Policy and Planning. (pp. 93-112). NY: Oxford Univ. Press. https://doi.org/10.1093/oxfordhb/9780190458898.013.4

Wodak, R., Meyer M. (2001) Methods of Critical Discourse Analysis. London: SAGE. http://dx.doi.org/10.4135/9780857028020

Wodak, R., Reisigl, M. (2001) The Semiotics of Racism. Approaches in Critical Discourse Analysis. Vienna: Passagen Verlag. 